\title{
How to prolong labour market participation in the Republic of Croatia?
}

ANA OSTROVIDOV JAKŠIĆ, mag. oec.* IVAN JAKŠIĆ, MD*

Review article**

JEL: J14, J21, H55

https://doi.org/10.3326.pse.43.1.6

\footnotetext{
* The authors would like to thank two anonymous referees for helpful comments on the paper. The views expressed are those of the authors and do not necessarily represent those of the institutions they are employed in.

${ }^{* *}$ Received: June 1, 2018

Accepted: November 26, 2018
}

The article was submitted for the 2018 annual award of the Prof. Dr. Marijan Hanžeković Prize.

Ana OSTROVIDOV JAKŠIĆ

Ministry of Labour and Pension System, Ulica grada Vukovara 78, 10000 Zagreb, Croatia

e-mail: anaostrovidov@gmail.com

ORCiD: 0000-0002-4794-4936

\section{Ivan JAKŠIĆ}

Nuclear medicine specialist, Clinical Hospital Centre "Sestre milosrdnice", Vinogradska cesta 29,

10000 Zagreb, Croatia

e-mail: iv.jaksa@yahoo.com

ORCiD: 0000-0001-8776-0560 


\section{Abstract}

The paper analyses the labour market for older workers from the point of view of prolonging their participation in the labour market in the Republic of Croatia. Due to unfavourable demographic situations, longer life spans and the threats to pension insurance systems, there have been many initiatives, in a number of countries, in the last couple of decades that have the goal of facilitating longer working lives. The current analysis has shown that older workers in the Republic of Croatia, despite their economic activity being lower than that of other countries, do have the additional working capacity that can permit longer labour market participation, without compromising the employment of younger cohorts. It has also shown that the labour market of the Republic of Croatia is not well suited to older age groups and that those with higher education and financial security, those who generally have the most opportunities, have the best chances for longer labour market participation; while the odds are against longer labour market participation for those with lower education, socioeconomic status and health, even if they might sometimes be willing to participate in the labour market,

Keywords: older workers, working life, labour market, Croatia

\section{INTRODUCTION}

In most of the developed countries, life expectancy is rising, while the demographic picture is increasingly poor, which has a negative effect on economic development, the fiscal sustainability of the social security system, the poverty risk among the old and on the development of the labour market. The numbers of pensioners are ever greater, and the share of the working age population is on the decline, leading to a situation that is sustainable only with difficulty, and hence attention is being directed towards encouraging longer labour market participation for the elderly.

The fall in the share of economically active elderly people started back in the seventies and eighties, when numerous countries endeavoured to resolve problems of unemployment with pensions reforms, which in effect came down to large-scale early retirement (Gruber, Milligan and Wise, 2009), reflecting and implementing the theory that the retirement of older persons would free up jobs for the young. ${ }^{1}$ This theory was shown to be fallacious several times over the years, ${ }^{2}$ and quite the opposite was actually proved. In countries that had a higher labour force participation rate of the elderly, youth unemployment was lower (Gruber, Milligan and Wise, 2009; Kalwij, Kaptejn and de Vos, 2009; Eichhorts et al., 2013). Alternately it was found that large scale early retirement could create jobs for a short time, but in the long term it led on the whole to a shortage of labour supply.

\footnotetext{
${ }^{1}$ The "lump of labour" theory claims that the quantity of jobs is fixed and that older workers can take the place of younger. The theory was first raised in Mayhew's London Labour and the London Poor, 1851; Mayhew claimed that a reduction in the hours of work could reduce unemployment (Munnell and Yanyuan Wu, 2013). ${ }^{2}$ First of all by David Frederick Schloss in 1891 (for more, see Munnell and Wu, 2013), and in more recent times the most important rebuttal is considered a series of findings for 12 countries in the framework of the National Bureau for Economic Research (NBER), USA (Gruber and Wise, 2010).
} 
Notwithstanding the evidence, even today in many countries the assumption can be found that the longer the old remain in the labour market, the fewer will be the opportunities for the young to be employed, for after all, at the micro-level, the departure of an older worker to retirement will free up a job for which someone new can be taken on (Eurofound, 2012b). The consequences of this approach include the situation in which people today spend a comparatively short time in the labour market, while the lifespan, as a result of better living conditions and medical advances, is ever longer.

The trend towards advocating longer labour market participation began at the beginning of this century. The OECD published its Live longer, work longer report in 2006, the EU named 2012 the European year for active ageing and solidarity between generations (Decision no. 940/2011/EU). The main emphasis here was on the specifics of the labour market for the elderly, that is, the huge influence of the pension systems of the countries, which made possible numerous exit routes from the labour market and in this way skewed decisions to remain in the labour force (Blöndal and Scarpetta, 1999).

There has been in most developed countries in the last few decades a marked improvement, with a rise in the labour force participation rate of the elderly (European Commission, 2015), particularly in those above the age of 60 (graph 2). However, in the Republic of Croatia, the share of the economically active elderly is far from keeping up with this rise.

This paper will attempt to provide answers to the question why people in the Republic of Croatia leave the labour market earlier than people in other countries, and what opportunities there are for encouraging longer participation in the labour market.

We envisage the contribution of the paper to be in its estimation of the possibilities of prolonging the working age and in raising awareness of the crucial necessity for changing the trend of early labour market exit in the Republic of Croatia.

This is a broad area of concern that touches on retirement policies, the labour market, social policy, health care, demography, education and labour law. Accordingly, the paper is founded on the structure of elementary, relevant and comparable data accessible in the following databases: Eurostat, the OECD, the Croatian Pension Insurance Institute (HZMO), the Croatian Employment Service (HZZ), the database of Mortality.org, the Croatian Bureau of Statistics (DZS), the Eurobarometer dedicated to active ageing of 2012 (below: Eurobarometer), reports of social security programmes worldwide (ISSA) and data from the Survey of Health, Ageing and Retirement in Europe (below, SHARE).

For the purpose of arriving at as good an estimate as possible, these data for the Republic of Croatia will be compared with data from other countries, selected on 
the criteria of accessibility of information in the databases and in SHARE research and according to the differences in the level of labour force participation rate of elder groups, the retirement policy, the degree of development of the labour market, the conditions in the labour market, and the educational structure of older workers.

The paper has three parts. Part 1 gives an overview of the labour market for older workers in Croatia and evaluates the possible additional working capacity for a longer labour market participation. Part 2 discusses the specifics of the labour market for older people, the factors that affect the decisions of individuals to stay in the labour market, the rationale of their intervention and effectiveness. It also analyses the capacities of the Republic of Croatia to prolong the working life within the framework of the retirement policy, adjustment of the labour market and the individual characteristics of older workers. The third part identifies groups that are most likely to stay longer in the labour market, with the help of which an estimation is made of the levels of choice that older workers have to stay in the labour market in the Republic of Croatia.

\section{THE LABOUR MARKET FOR OLDER WORKING PEOPLE}

For some number of years, Croatia has been faced with the increasing problem of a declining population. This is a problem that in combination with emigration (Stubbs and Zrinscak, 2018) and the low level of labour force participation rate has additionally exacerbated the problem of the reduction of the labour supply.

The proportion of the 50 to 64 age group in Croatia was 21.6 per cent in 2017; that of the 65 to 79 age group 14.6, both levels being higher than the EU-28 average. It is estimated that by 2080 in Croatia the old-age dependency ratio will be 58.6 per cent. ${ }^{3}$ In conjunction with this, Croatia has one of the lowest birth rates, 1.4 per cent in 2016. The life expectancy for women in 2018 was 81.4 years, and for men 75.4 , and it is growing, as it is in most countries, as a result of better living conditions and medical advances. ${ }^{4}$

Notwithstanding the improvements of the last few years, the Croatian labour market is characterised by a low labour force participation rate. In 2016, the rate was 65.6 per cent, only that in Italy being lower ( 64.9 per cent), while the EU- 28 average was 73.2 per cent. The employment rate was also at low levels and for the same year came to 56.9 per cent, only that in Greece being lower, at 52 per cent, the EU-28 average being 66.8 per cent. ${ }^{5}$

\footnotetext{
${ }^{3}$ These indicators are the ratio between the projected number of persons above the age of 65 (the age at which on the whole people tend to be economically inactive) and the projected number of persons in the 15 to 64 age group (Eurostat metadata).

${ }^{4}$ Source: fragment, Eurostat, accessed May 12, 2018.

${ }^{5}$ OECD.Stat accessed May 13, 2018 (Employment rate and Labour force participation rate refers to the 15 to 64 age group).
} 
According to Eurostat estimates, the duration of working life of people in the Repub-

lic of Croatia was 32.2 years in 2016, while the EU-28 average was 35.6 years. ${ }^{6}$

If they once become unemployed, on the whole older workers tend to stay unemployed, while some are discouraged. According to OECD, the share of discouraged workers in the 55 to 64 age group in Croatia rose from 2.9 per cent in 2007

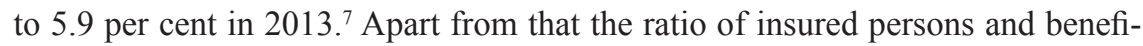
ciaries is highly unfavourable. This was partially caused by the financial crisis of 2009, as a result of which the number of insureds was reduced, and in 2014 it reached the lowest figure of 1.14:1. After that there was a slight rise, and in 2016 the ratio was 1.17 insureds to 1 dependant. $^{8}$

\section{GrAPH 1}

Labour force participation rate by the age groups, 2016

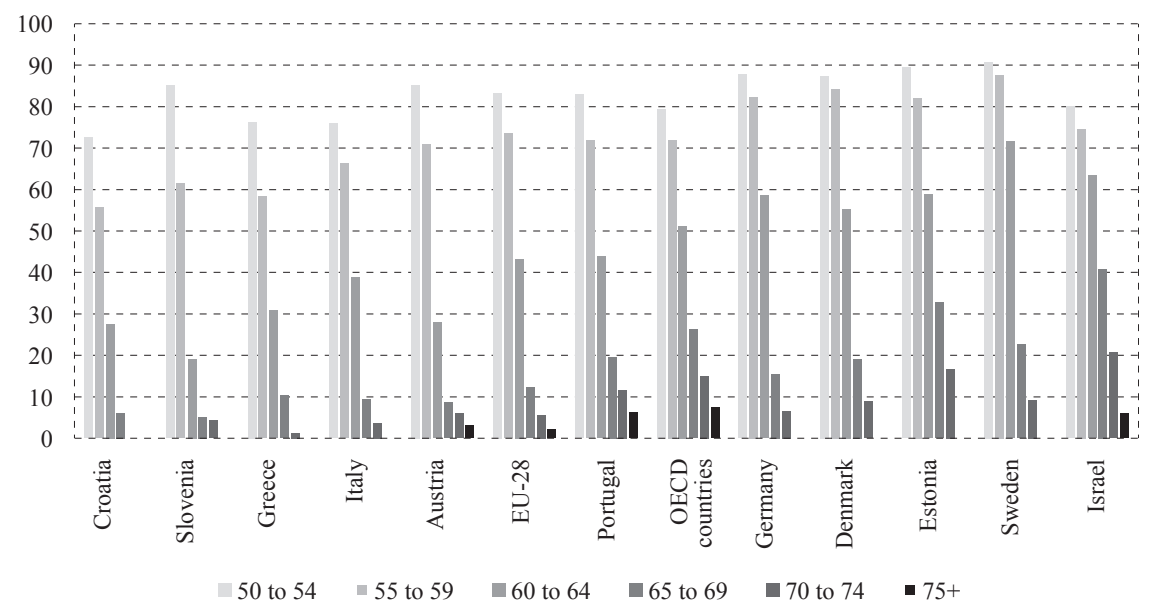

Source: OECD.Stat, accessed May 4, 2018.

In consequence, there is good reason for concern about the sustainability of the system and such a state conduces to the fact that the labour market, i.e. the economy, of Croatia will to a greater extend depend on older working people. Thus, in the report of the European Commission for 2017 (European Commission, 2015:311) Croatia is recognised as a country in which the negative consequences of the ageing of the population are particularly marked, together with the low levels of employed older people.

OECD data of 2016 put Croatia among countries where a short working life is accompanied with low labour force participation rate (graph 1). ${ }^{9}$

\footnotetext{
${ }^{6}$ The duration of working life indicator (DWL) measures the number of years a person aged 15 is expected to be active in the labour market throughout his/her life (Eurostat metadata). Eurostat, accessed May 12, 2018.

${ }^{7}$ Source: OECD.Stat, accessed May 14, 2018.

${ }^{8}$ Source: HMZO.

${ }^{9}$ Worth mentioning is that the Labour Force Survey, on which the OECD data and Eurostat data are based, do not differentiate those working in the official and in the unofficial economy, all of them are just employed. The same holds true for SHARE research.
} 
In younger age groups (50 to 59) the labour force participation rate is lower in Croatia than in other countries, however, this divergence is less than it is in the above-60 age groups. Of the countries from the comparison, activity level of the younger age groups (up to 59) is similar to that of Greece and Italy, while in the older groups $(60+)$ it is closer to Austria and Slovenia.

\section{GraPH 2}

Changes (increase/reduction) in the number of percentage points in the labour force participation rates from 2002 to 2016 for age groups 45 to 59 and 60 to 74

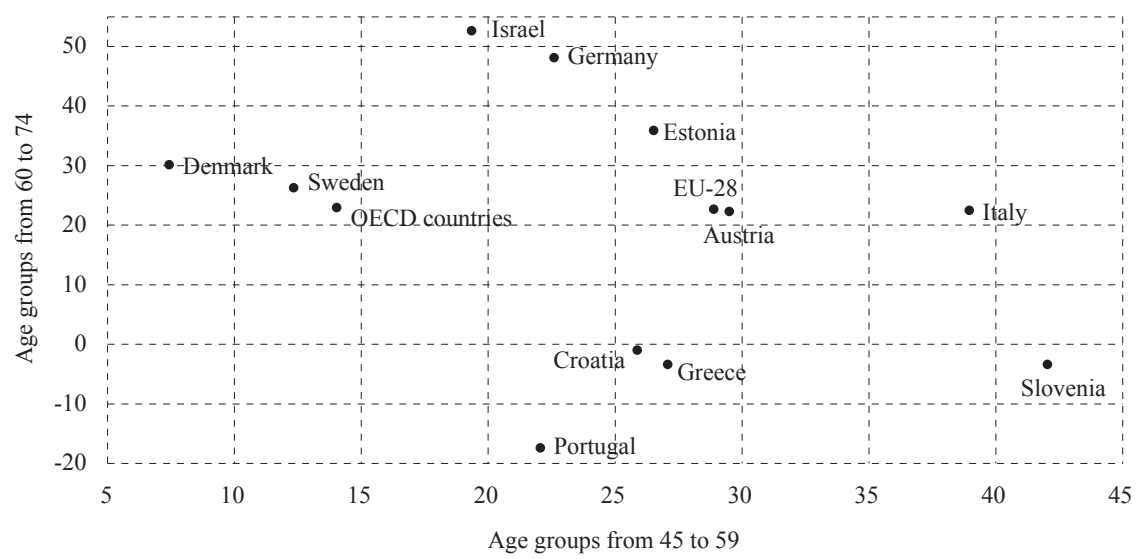

Source: OECD.Stat, accessed May 13, 2018.

If we look at the trends in the labour force participation rates of the older population in the last fifteen years in the countries of the European Union, we can see that the rates of those who are active has increased considerably. Croatia is to some extent keeping up with this growth in the up to 59 years of age group, but the older age groups have recorded a decline,${ }^{10}$ positioning the country with a small number of others (graph 2). The employment rate in the same period in Croatia trended in a similar way to that of the degree of labour force participation rate.

\subsection{IS THERE ANY WORK CAPACITY FOR LONGER LABOUR MARKET PARTICIPATION IN CROATIA?}

As in most countries, the population of the Republic of Croatia lived on average in the last century much shorter, but participated in labour market longer than is the case today, as can be seen from the graph 3. We shall use the difference in economically active population in 2015 to that of the past, 1971 to be precise, for an estimation of the possible additional work capacity of the population. The calculation will be done only for the male labour force because the display is more realistic, since the activation of the female labour force started in the seventies.

\footnotetext{
${ }^{10}$ For the 70 to 74 age group there is no recorded labour force participation rate in the Republic of Croatia in 2016, while in 2002 the rate was $6.7 \%$.
} 
This method is implemented according to the paper of Milligan and Wise (2012a), ${ }^{11}$ done within the NBER project and it is adjusted to the comparable and accessible data for the Republic of Croatia. The method is based on a reduced mortality rate over the years, which is also used as measure of health, that is, a depiction of the better health situation of the population and an increased lifespan. ${ }^{12}$ In terms of years of age, we see that in 1971 at the age of 59, 59 per cent of the male population was economically active, and that the level of mortality at the age of 59 in the year 1971 is the same as the level of mortality of the age 65 in the year 2015, the main difference being in the level of economic activity - between 59 per cent and 8.7 per cent. The cumulative sum of that difference in terms of years of age (table 1), gives us additional working capacity of 6 years.

\section{GraPh 3}

Labour force participation rates and mortality rates, men, 1971, 2015

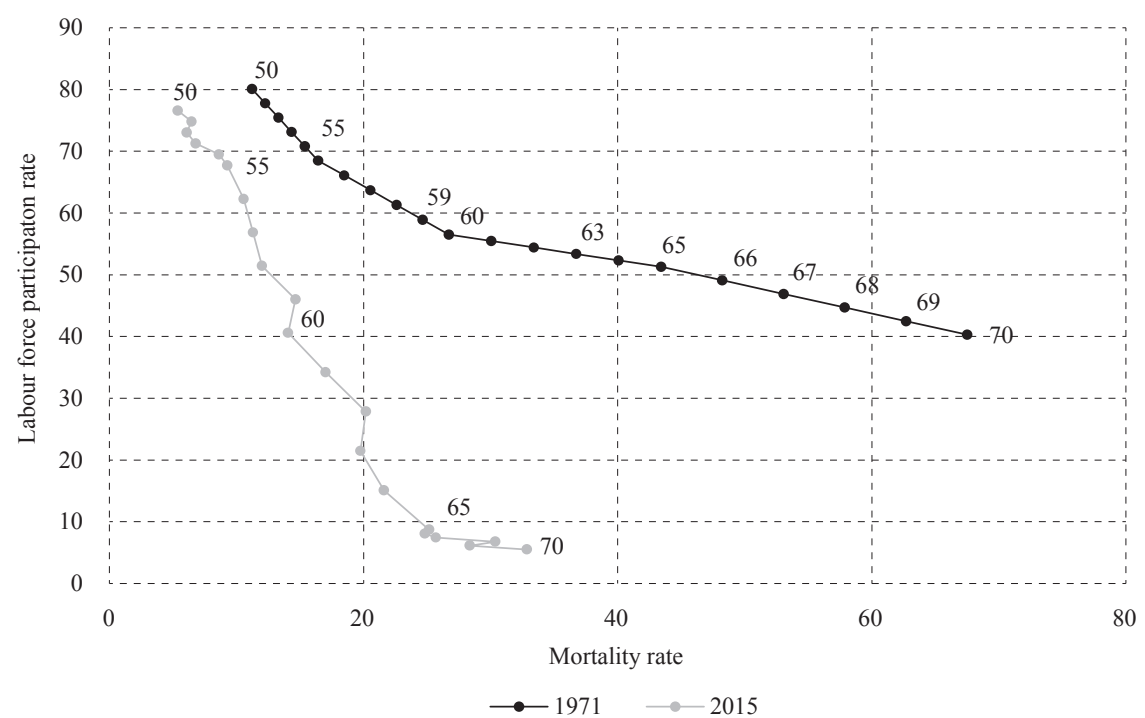

Note: individual rates for most of the data were obtained by a linear interpolation from fiveyear groups.

Source: Akrap, 2006:136 (after 1971 Census); Statistical Yearbook of Croatia 1971-1989; OECD Stat, Mortality.org, accessed May 20, 2018.

\footnotetext{
${ }^{11}$ The seventh phase of the NBER project Social Security Programs and Retirement Around the World, the objective of which is a comparison of the experiences of 12 developed countries concerned with the impact of social contributions on retirement and related issues.

${ }^{12}$ Clearly, mortality is not the same as morbidity, and other measures of health status, which are based on a large number of health indicators (Milligan and Wise, 2012b) and that all the increase in lifespan is not necessarily spent in additional work years (Coile, Milligan and Wise, 2016). However, an integral analysis according to health indicators would assume a much greater and more detailed study focused only on health, which is not the case in the present paper.
} 
Possible extra work capacity, men in 2015 as against 1971

\begin{tabular}{|c|c|c|c|c|}
\hline Age & $\begin{array}{c}\text { Labour force } \\
\text { participation } \\
\text { rate } 2015\end{array}$ & $\begin{array}{l}\text { Mortality } \\
\text { rate } \\
2015\end{array}$ & $\begin{array}{c}\text { Difference in labour } \\
\text { force participation } \\
\text { rates }\end{array}$ & $\begin{array}{c}\text { Cumulative } \\
\text { calculation of extra } \\
\text { work capacity }\end{array}$ \\
\hline 55 & 0.677 & 0.009 & 0.145 & 0.145 \\
\hline 56 & 0.623 & 0.010 & 0.196 & 0.342 \\
\hline 57 & 0.569 & 0.011 & 0.228 & 0.570 \\
\hline 58 & 0.514 & 0.012 & 0.268 & 0.838 \\
\hline 59 & 0.460 & 0.015 & 0.262 & 1.099 \\
\hline 60 & 0.406 & 0.014 & 0.335 & 1.434 \\
\hline 61 & 0.342 & 0.017 & 0.333 & 1.767 \\
\hline 62 & 0.278 & 0.020 & 0.368 & 2.136 \\
\hline 63 & 0.215 & 0.020 & 0.417 & 2.553 \\
\hline 64 & 0.151 & 0.021 & 0.477 & 3.029 \\
\hline 65 & 0.087 & 0.025 & 0.502 & 3.531 \\
\hline 66 & 0.081 & 0.025 & 0.504 & 4.035 \\
\hline 67 & 0.074 & 0.026 & 0.500 & 4.535 \\
\hline 68 & 0.068 & 0.030 & 0.485 & 5.020 \\
\hline 69 & 0.061 & 0.028 & 0.497 & 5.517 \\
\hline 70 & 0.055 & 0.033 & 0.491 & 6.009 \\
\hline
\end{tabular}

Source: as in graph 3, authors' calculation.

A computation of the possible additional working capacity for the more recent period from 2002 to 2015 (graph 4) according to the same principle and according to the original method of calculation, with the employment rate instead of economic activity, gives the result of 10 months of extra working capacity, mainly relating to groups after the age of 62 , the degree of employment of which is now lower than it was at the beginning of this century.

\section{GraPH 4}

Employment and mortality rates, men, 2002 and 2015

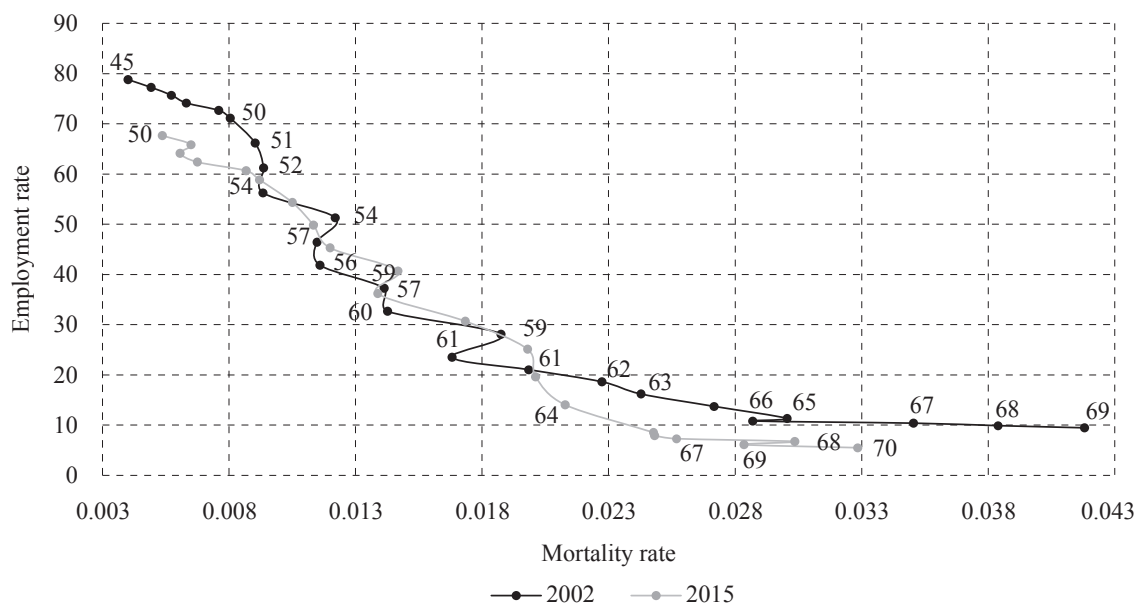

Note: as for graph 3.

Source: OECD.Stat, Mortality,org, accessed May 20, 2018. 
As a result of this it can be concluded that there is in Croatia additional working capacity for longer participation in the labour market. The levels of economic activity and employment have moved with the same intensity, and in both rates, it is clear that the number of people who participate in the labour market in their sixties is in continuous decline.

\section{FACTORS THAT AFFECT THE LABOUR MARKET FOR OLDER WORKING PEOPLE}

The labour market for older workers is marked by a number of specific features. First of all, there is no age above which someone can be unambiguously defined as old. The features and capacities of people of the same years of age can often vary considerably both physically and mentally depending on their previous experience of life and work, their physical predispositions and many other factors. ${ }^{13}$

In addition, the labour market for older people is much impacted by the pension system, as a result of which there are eight possibilities of work - retirement status (Scherger et al., 2012). People who are younger than the retirement age can be employed and unemployed, recipients of early retirement, with and without paid work. After the retirement age, people can be recipients of pensions, with or without paid work, they may have deferred their retirement and are still at work, while there are also those without the right to a pension, who are either employed or unemployed.

In endeavours to prolong working life, most often used are changes in the pension system. These efforts can be divided into two parts, pre- and post-retirement; before retirement, they would relate to raising the retirement age and flexibilising the age of retirement, i.e. early and deferred retirement. After retirement, they include flexible pensions, in other words, partial retirement, or paid work during retirement. But these institutions, according to the most recent analyses (OECD, 2017) have not sufficiently met expectations, referring here particularly to lesseducated groups.

Not only are changes in the retirement insurance system instrumental, but prolonged participation also depends on the level of the adjustment of the labour market to older workers. It is proved that people who stay longer in the labour market are more often self-employed (Hochguertel, 2010; Wahrendorf et al., 2017) and work part-time with a flexible working hours (Johnson and Kawachi, 2007 for the US; Eurofound, 2012 for EU countries; Burtless, 2013). The possibilities of work in flex-time/part time that can be adjusted to the needs of older workers are very important, logically, because the older labour force is a highly heterogeneous group. As a result of this, a more liberal and flexible labour market

\footnotetext{
${ }^{13}$ The definition of older workers according to most statistical databases refers to the age of from 55 to 64 (Eurostat, OECD). The WHO makes 45 the dividing point between older and younger (Reischl, 2007). The UN defines people of 60 as older (e.g., United Nations, 2015), and the ILO (ILO, 2013b) defines older people as those of advanced years. An active labour market policy in most countries, including Croatia, defines older persons as those above the age of 50, and according to Eurobarometer, the age of 63.9 years is the average age at which a person is considered old.
} 
offers more opportunities to older workers (Dalen et al., 2006), while a more conservative market will promote early retirement as a way of exiting the labour market in order to resolve the problem of unemployment (Bredgaard and Tros, 2006; Scherger, 2015).

However, prolonged participation, or the decision to take a pension, continue working or working while retired, along with the retirement policy and adaptation of the labour market most depend on individual characteristics, that is, the level of control possessed by the individual. In fact, then, there are two extremes - some that can choose and have complete control, and others, who have no choice (Phillipson and Smith, 2005). Those that can choose and have control in most countries are those who have greater chances to stay longer in the labour market. According to most research, these are better educated people who have not been employed in hard manual labour, and in general people with a better socio-economic status and better health (Komp, Tilburg and Broese van Groenou, 2010; Burtless, 2013; European Commission, 2015; Principi et al., 2015; Wahrendorf et al., 2017). They wish to continue to work to keep up their standard of living, better opportunities in the labour market, social contacts, job satisfaction (Scherger et al., 2012; Scherger 2015), keeping up daily routines and the possibility of working in flex-time/part time (Sewdas et al., 2017). Some (Burtless, 2013; European Commission, 2015; Qi, 2016) locate the cause of increasingly prolonged participation in the labour market in the share of better educated people being in most developed countries higher than before.

On the other hand, it is quite common for people to remain in the labour market because they are forced to out of sheer necessity (Scherger et al., 2012; Principi et al., 2015; Scherger 2015).

\subsection{CHANGES IN THE PENSION SYSTEM}

\subsubsection{BEFORE RETIREMENT}

The retirement age is the most standard characteristic of retirement systems (Gal, 2005), and lifting the age of early retirement has proved to be the most effective method for prolonging the working lifetime (Eichhorst et al., 2013; Konle-Seidl, 2017). However, although people today live longer and spend more time retired than before, there is still a great resistance among a large number of people to the idea of raising the retirement age (OECD, 2017).

In Croatia, along with some other countries, most respondents, a full 81 per cent, stated that they do not agree with a raising of the retirement age in the future (Eurobarometer, p. 67); it is worth mentioning that according to the so-called Bismarck-model of retirement insurance, that is in use in Croatia, the initial retirement age was 70 years, with 30 years of contributions, an age that at that time no more than 5 per cent of insureds had a chance of reaching (Puljiz, 2007).

Staying in the labour market can also be encouraged by tightening the conditions for early retirement (such as permanent diminution in the amount of a pension if it is taken earlier), and also for being able to claim a disability pension ( $\mathrm{Gal}, 2005$; 
Bredgaard and Tros, 2006; Konle-Seidl, 2017). What is more there is increasing stress on the importance of being informed in good time before early retirement, for people often hurry to take their pension and underrate the financial needs of retirement and live in poverty.

In the Republic of Croatia, for more than thirty years, up to 1999, early retirement was used very advantageously, enabling people to retire at the age of 50 (Balokovic, 2011). This was particularly marked in the nineties (graph 5) when the number of retirees grew substantially, as a result of which the ratio of insurance payers to pensioners fell sharply $(1980,3.46: 1 ; 1990,2.83: 1 ; 1999,1.38: 1$, after Puljiz (2007:170) and HZMO statistics). This was the consequence of both war and transition, while at the same time in some countries the activation of older age groups had already started. ${ }^{14}$

\section{GRAPH 5}

Changes in the retirement age and the number of pensioners in Croatia (including old-age, disability and survivors 'pensions)

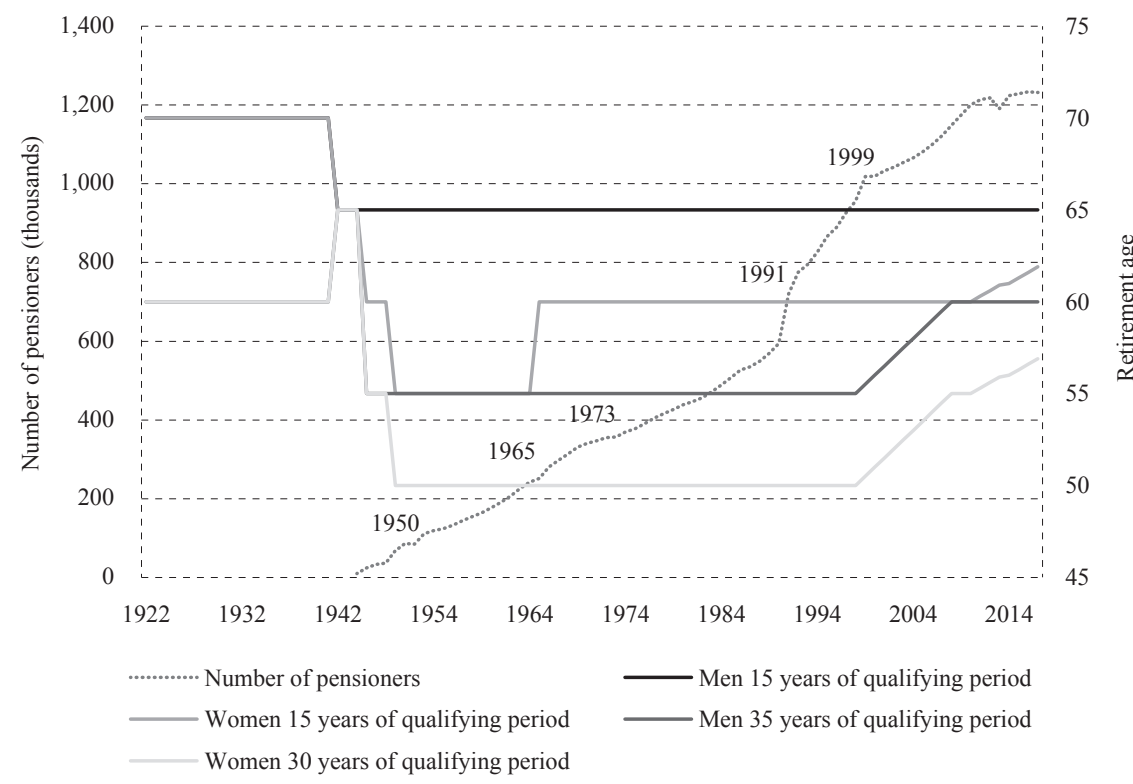

Note: because of the difference of conditions in retirement, it is hard to draw an exact parallel between the regulations in different periods. The graph approximately shows the years of qualifying periods needed for retirement, but they differ. For example, in the 1947 to 1950 period, for a retirement age of 65 for men and 60 for women, the requirement was 25 years of qualifying periods, and the retirement age of 55 related to qualifying period for full pension, while there were different requirements for hard and very hard jobs. Another example is the 1965 to 1998 period, when with 20 years of qualifying period it was possible to retire at 60 (men) and 55 (women) and so on.

Source: HZMO, 2002; Statistics of HZMO.

\footnotetext{
${ }^{14}$ As well as early retirement, it is worth mentioning a large number of other forms of retirement: disability retirement, work injury retirement with the right of placement, in other words, employment (from 1996 to 1998) and other (HZMO, 2002). However, considering the scope of the material, this work will not in detail analyse their influence on the economic activity of the labour force.
} 
The pensions reform of 1999 made the system more rational and tightened up the criteria for retiring and acquiring disability pensions, introduced a tripartite pension insurance system and raised the retirement age over the following 10 years (graph 5). ${ }^{15}$

According to Eurostat (the ad-hoc module) in Croatia in 2012 the average age at which a person first received an old-age pension was 57.7, while the EU-28 average was 59.1 .

\section{GRAPH 6}

Share of pensioners in total number of respondents, in age groups

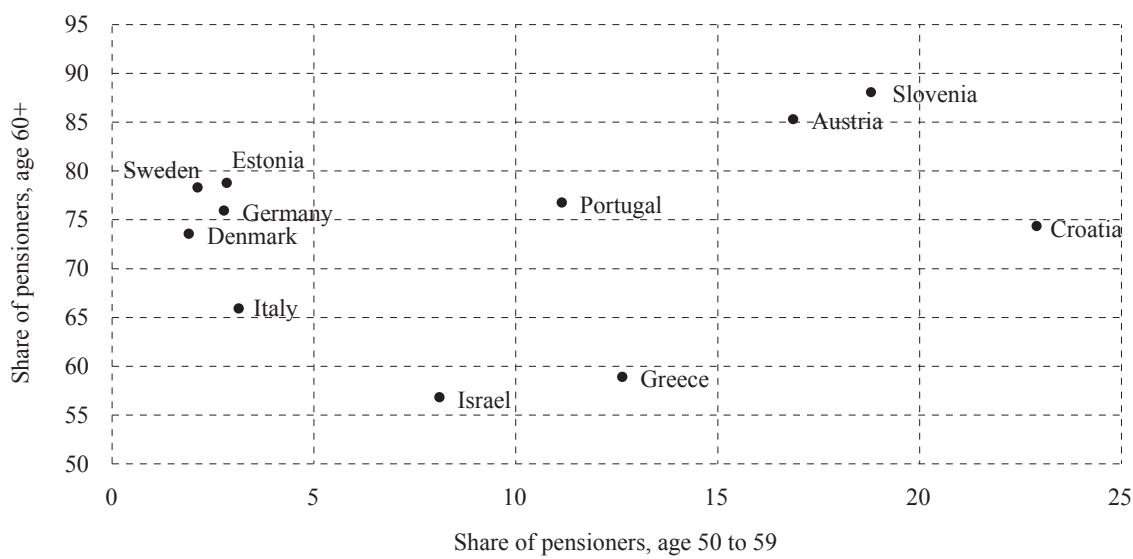

Note: in 2016 the retirement age in Croatia, for an old age pension was 65 for men and 61.5 for women, and for early retirement 60 (35 years of qualifying periods) for men and 56.6 (31.5 years of qualifying periods) for women. For a comparison, the retirement age in 2016 was in some countries the same as in the Republic of Croatia (65), more specifically, in Austria (60 for women), Denmark and Slovenia; in Estonia, somewhat lower (63) and in others higher: Germany $(65,42)$, Italy (66, 58 and 65, 58 for women), Portugal $(66,17)$, Greece (67 and 62 for women), Israel (70 and 68 for women). The age of early retirement was in most countries higher than in the Republic of Croatia: Austria (64 and 59 for women), Germany (63), Italy (63), in Estonia (60) and in Slovenia 59, 33 and 59 for women. Other countries have no early retirement age, or only for specific groups, information is not available, or the pension is awarded at any age if certain qualifying conditions are met; in Sweden, retirement age is flexible (ISSA, 2017a, 2017b).

Source: SHARE research.

In the same year, the share of pensioners in Croatia in the 50 to 69 age group was 47.1 per cent, 55.9 per cent of whom had retired early, while the contemporary equivalent for the EU-28 was 41.5 per cent and 39.1 per cent, respectively. ${ }^{16}$ Thus although the raising of the retirement age (graph 5) had increased activity in the up-to-59 age group from the time before the pension reform (graph 2), Croatia still has a high share of rather young pensioners (graph 6). People in Croatia much more, on average, retire early (Rutkowski, 2007) and it is the most frequent

\footnotetext{
${ }^{15}$ Between 2011 and 2029 the ages for women will become the same as those for men. The third period of enlargement is from 2031 to 2038 for early retirement from 60 to 62 and from 65 to 67 for old age retirement (Pension Insurance Act).

${ }^{16}$ Source: Eurostat, accessed May 14, 2018.
} 
manner in which people get out of the labour market. It has to be said here that many countries have tightened the conditions for early retirement, with Austria particularly standing out in the selected countries; in Israel, early retirement is not possible (OECD, 2017).

Another way in which the retirement age is made more flexible is deferral, which many countries encourage, the main stimulus for deferral being an ultimately higher pension amount (Blöndal and Scarpetta, 1997). In Croatia, this is possible, on certain conditions. ${ }^{17}$ However, although for some long time there has been discussion of integrating more powerful incentives for later retirement (Nestić and Rašić Bakarić, 2008), the take-up of this institution in Croatia is very low, as can be seen from the very low proportion of the economically active population above the age of 65 . In addition, only 35 per cent of people in Croatia think that people should be enabled to continue working after reaching the age of retirement (the EU-27 average is 61 per cent, Eurobarometer).

Examples of the successful implementation of this institute in the countries in the comparison are Estonia and in particular Portugal, where the annual bonus for deferral is up to 12 per cent and Austria, where the bonus for the first year of deferral is 8 per cent. Just the reverse can be seen in Greece in which up to the age of 67 there is no incentive for deferral (OECD, 2017).

An additional factor before retirement that disincentivizes staying in the labour market in Croatia is the linking of exit from the labour market with the $65^{\text {th }}$ birthday. According to the Labour Act (Article 112, Paragraph 4) and the Civil Servants Act (Article 137, Paragraph 3) an employment contract (a civil service position) will cease when the employee (a civil servant) reaches the age of 65 and has a contributions record of 15 years, unless the employer and the worker (head of the body, the civil servant) come to a different agreement. It has to be said here that as many as 77 per cent of respondents in Croatia think there should be an age at which people must retire (Eurobarometer), while in the EU-27, 53 per cent have the opposite opinion.

In connection with this, in the Act on Employment Mediation and Unemployment Rights, in Article 17, it says, among other things, that a person will no longer be kept in the records after he or she turns 65 years of age. The same Act also prescribes the right to a longer compensation for unemployed older persons, that is, people who have five years to go to meet the conditions to be able to claim an old age pension, if they have spent more than 32 years working. This form of prolonged benefit for older unemployed persons has a negative impact on the participation of older people in the labour market (Blöndal and Scarpetta, 1999; Eichhorst et al., 2013).

\footnotetext{
${ }^{17}$ According to the Pension Insurance Act, Article 85, in the case of an insured who is granted pension for the first time after the age of 65 , and has 35 years of qualifying periods, shall be determined by increasing the initial factor by $0.15 \%$ a month for each month once the insuree has reached the age required for obtaining the right to old-age pension, and for no longer than five years.
} 


\subsubsection{AFTER RETIREMENT}

In the last few years there has been increasing advocacy of partial retirement (Eurofound, 2012b) ${ }^{18}$ as a flexible compromise between work and retirement that will keep older workers in the labour market (OECD, 2017). Partial retirement implies the possibility of paid work after retirement in conjunction with receipt of a pension or part of a pension. The hours of work are reduced, and the retiree is gradually accustomed to the new life in retirement, and can also transfer knowledge and experience to the young. ${ }^{19}$

Although today the systems of most countries permit the use of this institution and two thirds of respondents to polls like the possibility of working and receiving a pension (Eurobarometer), in Europe only about 10 per cent of people in the 60 to 69 age group do in fact combine work and retirement (OECD, 2017). There are several reasons for this weak implementation. In the first place, the institutional organisation of the ever more present work after retirement in many countries has not been completely elaborated and harmonised. For this reason, it may happen that pensioners who work do not have the same rights as other workers (minimum wage, unemployment insurance, sickness benefit) and that the contributions for this kind of work are the same as they are for workers who are not retired (Eurofound, 2012b). In addition, many countries prescribe the possibility of work after retirement, but not with the same employer (Heywood and Siebert, 2009) while in some countries one of the biggest obstacles is the general level of acceptance of part-time work (OECD, 2017).

According to HZMO (2002) work after being pensioned was possible in Croatia back in 1964, for claimants of old age pensions who had qualified by a qualifying period of 40 years (for men) and 35 years (for women).

In 2014, the possibility of being partially retired was introduced in Croatia, working up to half a working week with the retention of the right to the payment of a pension and the possibility of claiming the re-calculation of a pension (after at least an additional year of insurance contributions).

In more detail, partial retirement is permitted for claimants of old age pensions who continue to work up to the limit of half a working week with a changed

\footnotetext{
${ }^{18}$ Phased retirement, if work is done with the same employer, or partial retirement, if the employer is changed (Kantarci and Soest, 2008).

${ }^{19}$ Work after retirement was once common. The retirement insurance system of the $19^{\text {th }}$ century in Germany was not meant to replace earned income entirely, but only to supplement it, since it was assumed that earnings with age and infirmity would be lower, and pensions recipients often went on working. This was changed after WWII with a greater amount of retirement benefit (Scherger, 2015). E.g. countries with centralised economies had very low retirement ages, and pensioners were permitted to work if they wanted, without any curtailment of their pensions. In the USSR more than a half of all pensioners worked and also received their pensions up to a certain amount. The situation changed with the move to a market economy and with the increase of the numbers unemployed, when the policy of early retirement began to be used to free-up jobs (Samorodov, 1999). In Georgia, for example, 88 per cent of workers/retirees work as self-employed persons. Work during retirement is permitted, with no curtailment of the pension, with the exception of state and public employees, but including retirees working in the public sector in science and education (ILO, 2013a:76).
} 
employment contract, people on disability pensions because of occupationally derived incapacity to work or because of partial loss of work capacity, beneficiaries who carry out seasonal jobs in agriculture according to regulations concerning employment incentives and beneficiaries who have second incomes, or carry out some second activity.

Excluded are pensioners who take on jobs or start to carry out some activity pursuant to which the status of insured person can be acquired. ${ }^{20}$ For employed pensioners, all contributions are paid, as for other employees. ${ }^{21}$ It has to be said that pensioners who have some second income were from 2009 exempted from the calculation and payment of contributions on receipts from which the second income was determined, but this was rescinded in early 2017.22

\section{GRAPH 7}

Shares of people stating that they are pensioners and yet still worked in the private or public sector or were self-employed, by age groups

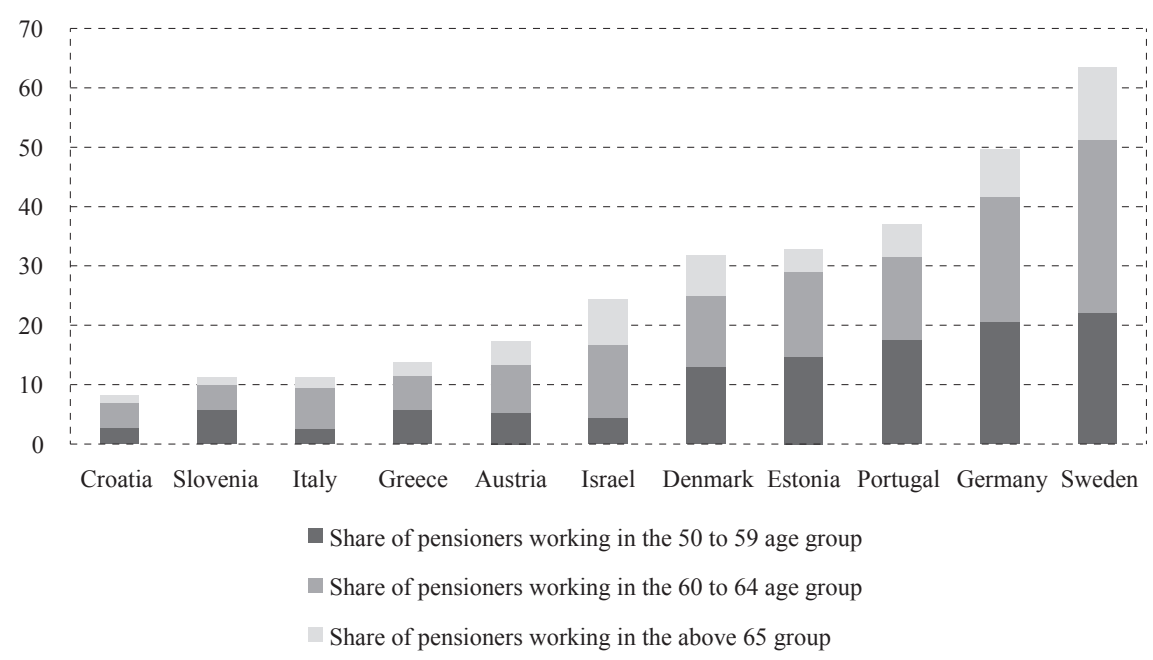

Source: SHARE research.

In consequence, although as many as 54 per cent of respondents in Croatia find the idea of working part time in conjunction with a pension acceptable (Eurobarometer), and although at the risk of poverty rate for pensioners is one of the highest

\footnotetext{
${ }^{20}$ The activity of a tradesperson, sole trader, freelancers (such as lawyers) and that, to be able to carry out this activity or profession have to be enrolled in the appropriate register (trades register, court register, professional register and so on).

${ }^{21}$ However, in the event of any temporary incapacity for work, they have no right to salary compensation charged to health insurance, rather it is charged to the employer (Article 50 of the Mandatory Health Insurance Act) and they are not exempt from the payment of the employment contribution at a rate of 1.7 per cent (Article 16 of the Contributions Act), while at the same time they are not considered unemployed persons (Article 10 of the Act on Employment Mediation and Unemployment Rights ).

${ }^{22}$ When the Contributions Act was changed (OG 115/16) the total rate of contributions for retirement insurance was made 10 per cent (for insureds in the first pillar), or 7.5 and 2.5 per cent for insureds of the $1^{\text {st }}$ and $2^{\text {nd }}$ pillars, and the contribution for mandatory health insurance is 7.5 per cent.
} 
in Europe, coming to 21.8 per cent, ${ }^{23}$ this institution has never been widely applied, only for a few people, as we can see in graph 7 , and in the decline in the labour force participation rate of older people since 2002 (graph 2).

In the countries in the sample, this institution has been employed to a great extent only in Sweden, which has a very flexible work-and-pension system and has no restrictions on earnings, just like Estonia and Portugal, while for example Denmark, Israel and Greece all restrict earnings during retirement. In the last two years the greatest growth in 65-plus workers has been in Slovenia and Austria (OECD, 2017).

\subsection{AN OLDER-WORKER-FRIENDLY LABOUR MARKET}

Part time work and self-employment are characteristics of a flexible labour market. Labour market flexibility can be divided into four kinds (Atkinson, 1984) but in this context we shall mention just two that are the most important for older workers, that characterise these two important forms of work and employment. These are the internal-numerical, which enables the adjustment of working conditions to the amount of jobs through flexible working time and the external-numerical, which is reflected in the framework of labour law that makes the hiring and firing of workers easier. ${ }^{24}$

Internal numerical flexibility is characterised primarily by part-time work, which is very important for older workers, for it is adjusted to their needs and capacities. Because of this, this form of work is widespread among older workers, which is for many a more acceptable approach than full retirement (Ghoseh, Lee and McCann, 2006), for people are not thus forced to choose between full time work and full retirement. In this way many countries have increased the share of employed older workers (ILO, 2013a; Eurofound, 2016) and according to some (Social Protection Committee, 2007) the growth of employment among the elderly happened as a result of the growing trend of part-time work.

Part time work has never been widely applied in the Republic of Croatia, so that the share of people who work in this way is very low (for the 15 to 64 age group, 4.8 per cent, in 2017, while the EU-28 average is 19.4 per cent), which distinguishes Croatia from most countries in the EU (Eurofound, 2016). ${ }^{25}$ All of this also refers to the labour market for older workers (graph 8), the difference being that for older workers the level of this kind of flexibility is extremely essential.

\footnotetext{
${ }^{23}$ The share of pensioners with an equivalised disposable income below the at-risk-of-poverty threshold. Eurostat metadata, accessed April 20, 2018.

${ }^{24}$ Two other are: functional and financial flexibility.

${ }^{25}$ Other indicators of this flexibility, like the share of people who work nights or weekends and so on (European Commission, 2013:72) are also low for Croatia. Source: Eurostat, accessed May 14, 2018.
} 


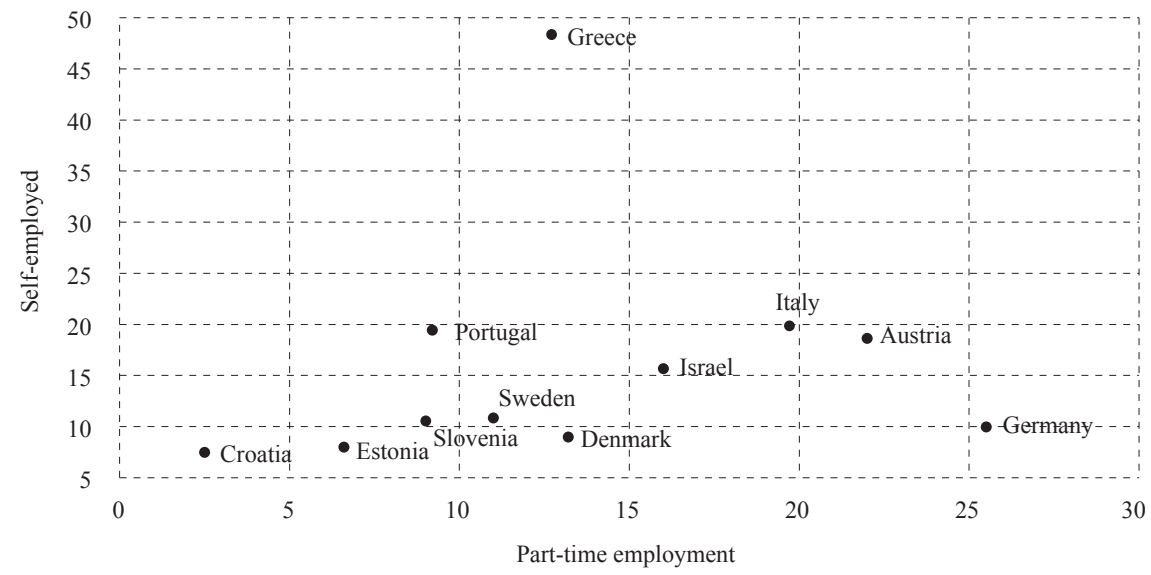

Source: SHARE research and OECD.Stat, accessed April 22, 2018.

External numerical flexibility in this context ${ }^{26}$ is characterised by a share of the self-employed (European Commission, 2013:72). This form of employment offers more flexibility in both directions, internal and external, that is, such people have greater freedom of choice about taking part in the labour market and the possibility of working with flexible timetables.

The share of older self-employed people in Croatia is very low, to which one has to add that the percentage of self-employed women from the mentioned data for Croatia is the lowest among all countries in the comparison. ${ }^{27}$

Therefore, the two main forms of work and employment for older persons in Croatia are used very little, from which it derives that the labour market is not olderworker-friendly.

\footnotetext{
${ }^{26}$ Very important indicators of this kind of flexibility are the indices of employment protection legislation (employment protection for regular contracts, including collective lay-offs and employment protection for temporary contracts). Indices that are exaggeratedly high, that is, with exaggerated statutory protection for the employment of older workers, which many countries use as tools in their anti-discrimination policies, can reduce their chances of being employed (Heywood and Siebert, 2009) and is linked with a low level of selfemployment (Christelis and Fonseca, 2015).

${ }^{27}$ In actual fact, the percentage of self-employed in Croatia for those older than 15 years is even a little higher than the EU-28 average (16.1 per cent as against 15.6 per cent for 2014, European Commission, 2015:385). There are several explanations for the lower percentage of older self-employed persons. According to the report of the European Commission (2015:49), in the new member states, which are marked by a background of the former centrally planned economies with the emphasis on dependence and conformism, the older generations show some resistance to the key characteristics of self-employment and enterprise, such as self-confidence and individualism. According to Botrić and Tomić (2016), in Croatia the older turn to self-employment out of necessity, not as an opportunity, and during the time of the Crisis, the percentage of older self-employed fell, which confirms the fact that the older workers often used early retirement as a way out of the labour market. Apart from that, according to Botrić (2012), in parts of Croatia where more people are employed in the public sector, there is a lower percentage of self-employment. In other words, work in the public sector is a safer way of being employed, and in Croatia (according to SHARE data) people from the up-to-64 group are much more employed in the public sector than they are in other countries, which is particularly brought out by the shares of men in the up-to-59 group and women older than 60 . However, for any establishment of a wider spectrum of influences, or causes of the low percentage of self-employed older people in Croatia, a more extensive and detailed analysis would be required.
} 


\subsection{INDIVIDUAL CHARACTERISTICS - THE EMPLOYABILITY OF OLDER WORKERS}

One of the main explanations for the increasing participation of older people in the labour market, along with the widespread availability of part-time work, is the fact that there is an even greater proportion of better educated older workers, that is, of those who have greater chance of staying in the labour market longer. We can use this fact to explain, for example, the prolonged participation in the labour market in Estonia, and the shorter in Italy and Slovenia (graph 9, graph 1), as well as the fact that those who are highly educated are more often employed in these countries (OECD, 2017). Croatia has a small percentage of people with tertiary qualifications, a somewhat higher percentage of people with elementary education, and the biggest group consists of those with secondary education, which will also partially go to explain the low labour market participation of older workers. However, although the better educated have the greatest chances of staying on in the labour market, in some countries even those who are more poorly educated have bigger chances of continued employment. In Denmark, for instance, in the period from 2002 to 2016 employment rate for lower educated older people, of whom Denmark has quite a lot (graph 9), rose the most (European Commission, 2015). Apart from that, a large percentage of this group is also employed in Sweden (over 60 per cent of the 55 to 64 age group), which is also evidence of a wellfunctioning labour market for older people, which provides greater chances of work for everyone (European Commission, 2015). Here one should also mention Portugal, which, in spite of the old labour force having a very unpropitious educational structure, nevertheless has a higher labour force participation rate of older people than the EU-28 average (graph 1).

\section{GraPH 9}

Population structures in \% of 55 to 64 age group according to educational levels, 2016

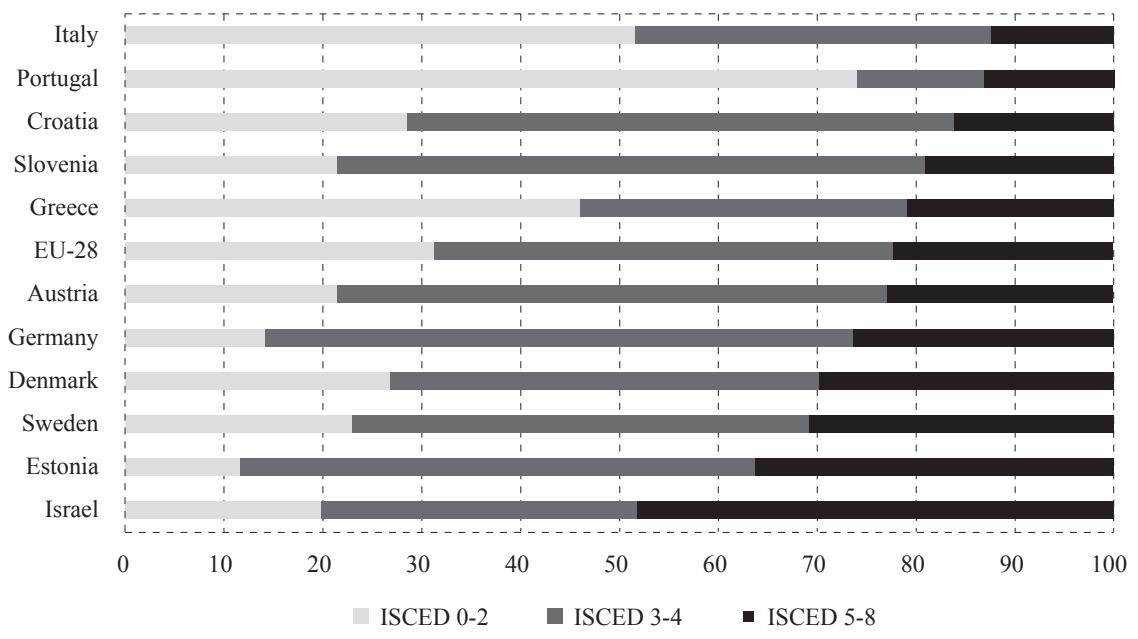

Source: Eurostat and OECD.Stat, accessed April 12, 2018. 
GraPh 10

Participation in LLL of the age groups from 50 to 60 and from 61 on

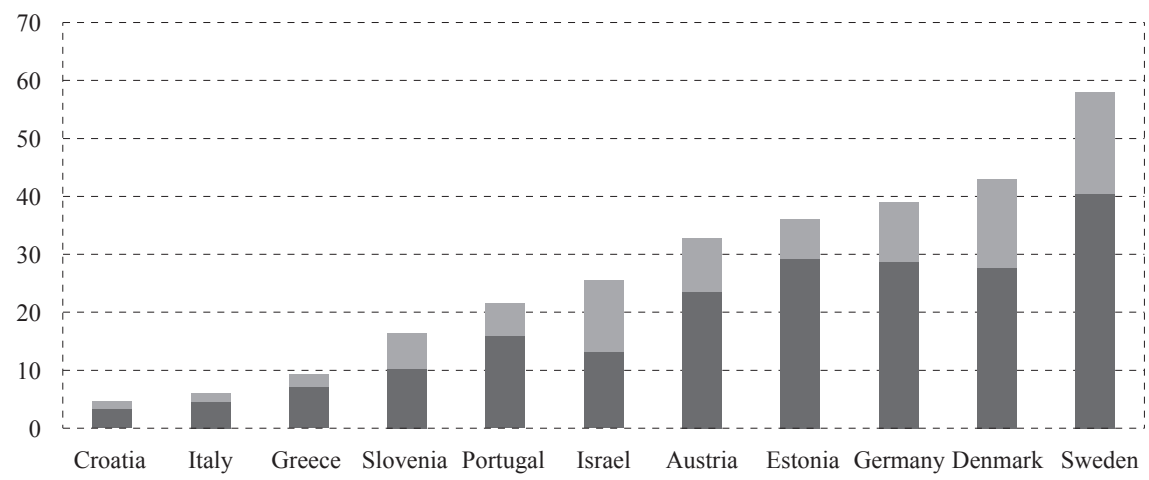

$\square 50-60 \quad \square 1+$

Note: figures relate to the share of respondents who stated that 12 months before the poll they attended an educational course or training event (the share of people who did not reply to this question is not covered by the percentage).

Source: SHARE research.

An important role in the prolongation of working life is participation in lifelong learning (Mayhew and Rijkers, 2004; Dalen et al., 2006), and it has been ascertained that people in countries where longer participation in the labour market is more common also have a greater share of participation in lifelong learning (European Commission, 2015:309). Continued education increases employability and provides better chances, and assumes the interest of individual or employer in investing in human potentials and, accordingly, a longer stay or retention of workers in the labour market. For the unemployed it is mainly in the scope of active labour market policies (ALMP). The lifelong-learning participation rate is on the whole a good fit with the educational structure (graph 10). Israel, Denmark, Sweden and Estonia have the highest percentages of highly educated and the highest percentage of participation in lifelong learning. An exception from this is Israel, with a somewhat lower participation in lifelong learning.

The lifelong learning involvement rate in Croatia is extremely low for the 25 to 64 age group as well (in 2017, only 2.3 per cent claimed that in the last four weeks before the poll they had taken part in education or training, which was one of the lowest results in Europe ${ }^{28}$ ). The SHARE rate for the above-50s is even lower (graph 10). In other words, the culture of investment in human capital and work on careers, particularly for those in the group of older people, is at a very low level.

Furthermore, a well-adapted ALMP can increase the employability of older people and provide opportunities for them to work. In this context, relief from taxes and other incentives has shown to be most effective (European Commission,

$\overline{{ }^{28} \text { Source: Eurostat, accessed May 15, } 2018 .}$ 
2015), because the only criterion is the age of the person, while a record in employment bureaus is not a condition, which is otherwise the usual precondition for participation in ALMP measures. ${ }^{29}$ However, in the Republic of Croatia, the ALMP for those over 50 is aimed only at those who are registered in the employment service. In principle, they can take part in almost all kinds of measure, except in programmes designed only for the young. The percentage of newly involved active labour market measure users in the age of from 50 to 54 in Croatia ranged around 10 in 2012 to 13.1 in 2016; at the same time the unemployment rate of people above the age of 50 ranged from 16 per cent in 2012 to 18.4 per cent in 2016. ${ }^{30}$ Of the countries in the comparison, Denmark, Sweden and Austria in general invest more in ALMP measures, Greece less. The Republic of Croatia is positioned in the middle $(0.4 \text { per cent })^{31}$, but this investment is mostly directed to the young, who have in the last few years been in the focus of the ALMP.

\section{WHAT LEVEL OF CHOICE IS THERE ABOUT LONGER PARTICIPATION IN THE LABOUR MARKET IN THE REPUBLIC OF CROATIA?}

A decision to continue participation in the labour market depends most of all on the control that an individual has, the greatest chances belonging to those who can choose, those who are better educated, healthier and generally have a higher socio-economic status. Conversely, the lowest chances of staying in the labour market is enjoyed by those who work because their financial situation is poor, with the level of choice, or the possibility of remaining in the market, also depend on all the factors that impact the older workers labour market. In the Republic of Croatia, for 59 per cent of people in the 50 to 69 age group, the main reason for remaining in the labour market was insufficient earnings (Eurostat, 2012, ad-hoc module). Hence, of the few people who do remain in the labour market, most of them do so out of financial necessity.

In order to identify what the possibilities for staying in the labour market in the Republic of Croatia are, a logistic regression model was constructed with employment set as the dependent variable. According to the previously stated basic characteristics the model tells us who in Croatia has the great chance of remaining in employment, and to what extent.

The model was constructed according to data from SHARE, a multi-disciplinary and international panel research that collected microdata in biennial waves of

\footnotetext{
${ }^{29}$ For example, in Austria up to 2012 firms paid 12.45 percentage points lower contributions for workers older than 60 (Eichhorst et al., 2013). In Spain social contributions were paid only in the amount of 50 per cent for the employment of workers over 60, and fell by 10 per cent until the worker had turned 65 (Eurofound, 2012a), while on Cyprus, as a result of the shortages of labour in some deficit occupations it was made possible for workers over 65 not to pay any contribution (Fortuny, Nesporova and Popova, 2003). Some authors have even proposed the founding of an agency for the employment of older workers, with lower contributions, part time, something like a student employment service (Ograjanšek et al., 2008).

${ }^{30}$ Data in greater details are not available. Source: Annual Reports of HZZ, OECD, accessed May 15, 2018. ${ }^{31}$ Public expenditure on ALMP as a percentage of GDP (category of interventions 1-7) for 2015. Source: OECD.Stat, Eurostat.
} 
research, interviewing those aged 50 and over in 27 European countries and in Israel. $^{32}$

This paper makes use of data from the $6^{\text {th }}$ wave of the research: the 6.0.0. version (Börsch-Supan, 2018), the specific data from this wave being accessible in Malter and Börsch-Supan (2017). Data were collected through field research with the CAPI method on a random sample; in total, 2,494 interviews were assembled from respondents aged 50 and above and their partners throughout Croatia. The methodological details of the actual research are available in Börsch-Supan et al. (2013), the specific schema of metadata of the $6^{\text {th }}$ wave in Börsch-Supan (2018) and the response rate in Bergmann et al. (2017).

\section{TABLE 2}

Summary of statistics

\begin{tabular}{|c|c|c|c|}
\hline & \multirow[t]{3}{*}{ Age group } & \multirow{2}{*}{$\begin{array}{c}50-60 \\
N=882 \\
\end{array}$} & \multirow{2}{*}{$\begin{array}{c}61+ \\
N=1,560\end{array}$} \\
\hline & & & \\
\hline & & & \\
\hline \multirow{2}{*}{ Employed } & Yes & 43.8 & 5.3 \\
\hline & No & 56.2 & 94.7 \\
\hline \multirow{2}{*}{ Gender } & Male & 41.3 & 46.5 \\
\hline & Female & 58.7 & 53.5 \\
\hline \multirow{3}{*}{$\begin{array}{l}\text { Educational level } \\
\text { ISCED2011 }\end{array}$} & $0-2$ & 49.4 & 64.2 \\
\hline & $3-4$ & 35.6 & 19.4 \\
\hline & $5-8$ & 15.0 & 16.4 \\
\hline \multirow{2}{*}{ Self-assessed health } & Worse than very good & 64.0 & 81.5 \\
\hline & Very good or excellent & 36.1 & 18.5 \\
\hline \multirow{2}{*}{$\begin{array}{l}\text { Self-assessed household } \\
\text { financial situation }\end{array}$} & With financial difficulties & 75.5 & 72.1 \\
\hline & Without financial difficulties & 24.5 & 27.9 \\
\hline
\end{tabular}

Source: SHARE data base, 6.0.0 version, authors' calculation.

The choice of control variables (gender, educational level, self-assessed health and self-assessed financial situation) came on the back of the findings earlier mentioned, that is, conclusions that those who have the choice according to these characteristics will stay longer in the labour market. The model was estimated for two age groups: the 50 to 60 and the 61 and above, because of the already established different levels of labour force participation rates (graph 1, graph 2). This division additionally cut the sizes of the samples as a result of which the number of categories of most of the variables was reduced. Thus, the categories of the dependent variable, employment, was reduced from the original six to just two: 1 - employed, self-employed, including work in the family business or trade, and 0 - retired, unemployed, permanently sick or disabled, homemaker and other. In the variable "self-assessed household financial situation", or the variable that answers the question "Taking into

\footnotetext{
${ }^{32}$ The SHARE database is primarily financed by the European Commission through FP5 (QLK6CT-2001-00360), FP6 (SHARE-I3:RII-CT-2006-062193, COMPARE:CIT5-CT-2005-028857, SHARELIFE:CIT4-CT-2006-028812) and FP7 (SHARE-PREP:N²11909, SHARE-LEAP:N²27822, SHARE M4: No261982). For details, see www.share-project.org.
} 
consideration its total monthly, would you say that your household makes ends meet?", it was possible to answer: "With great difficulty", "With a certain amount of difficulty", "Fairly easily" and "Easily", which for the purposes of the model were subsumed into two categories: with financial difficulties, which covered the first two categories, and without financial difficulties, which covered the second two. Then, the education variable was reduced from the 9 according to the levels of the International Standard Classification of Education (ISCED, 2011) to the following three, which by degrees encompass the original nine: lower level of education (0-2), secondary education (3-4), higher level education (5-8).

The results of the model show us the odds ratio (OR) that a person is employed in as against the reference categories shown in parentheses. Thus, for example, in the age of 50 to 60 for persons of educational levels ISCED 5-8 there is a greater probability of being employed (OR 4.26) than persons of educational level ISCED 0-2, while this ratio in the 61+ group is even greater (OR 5.21).

In short, according to the results, in the Republic of Croatia in both of the age groups observed, but more pronouncedly in the older (61+) group, the following have greater chances for remaining in employment:

- men,

- those with better self-assessed health,

- those with higher education, and

- those who live in households that they consider to have no major financial difficulties.

TABLE 3

Results of model of logistic regression on employment (1-yes, 0-no)

\begin{tabular}{|c|c|c|c|c|}
\hline & \multicolumn{2}{|c|}{$\begin{array}{c}50-60 \\
N=559\end{array}$} & \multicolumn{2}{|c|}{$\begin{array}{c}61+ \\
N=1,007\end{array}$} \\
\hline & Odds ratio & $\begin{array}{l}\text { Standard } \\
\text { error }\end{array}$ & Odds ratio & $\begin{array}{l}\text { Standard } \\
\text { error }\end{array}$ \\
\hline $\begin{array}{l}\text { Gender } \\
\text { (Men) } \\
\text { Women }\end{array}$ & $0.61 * *$ & 0.12 & $0.41 * *$ & 0.14 \\
\hline $\begin{array}{l}\text { Self-assessed health } \\
\text { (Worse than very good) } \\
\text { Very good, excellent }\end{array}$ & $2.28 * * *$ & 0.46 & $2.42 * *$ & 0.81 \\
\hline $\begin{array}{l}\text { Education } \\
\text { (ISCED 0-2) } \\
\text { ISCED 3-4 } \\
\text { ISCED 5-8 }\end{array}$ & $\begin{array}{l}2.58 * * * \\
4.26 * * *\end{array}$ & $\begin{array}{l}0.53 \\
1.26\end{array}$ & $\begin{array}{l}(2.2) \\
5.21 * * *\end{array}$ & $\begin{array}{l}0.93 \\
2.07\end{array}$ \\
\hline $\begin{array}{l}\text { Self-assessed household } \\
\text { financial situation } \\
\text { (With financial difficulties) } \\
\text { Without financial difficulties }\end{array}$ & $1.87 * *$ & 0.42 & $1.92 *$ & 0.63 \\
\hline $\mathrm{R} 2$ & & & & \\
\hline
\end{tabular}

Notes: $95 \%$ confidence intervals (CI); $* * * p<0.001 ; * * p<0.01 ; * p<0.05$.

Source: SHARE data, version 6.0.0, authors' calculation in Stata 14.2. 
Therefore, of the two basic groups of elderly people who remain in the labour market longer, that is of those who have the choice and those that do not, in Croatia a much greater probability of staying in employment is enjoyed by those that have the choice and the possibility, and there are very few of them, which explains the very low labour force participation rate of older people.

We can also establish that for people who are not in the groups described (i.e. those who are poorly educated, have low socio-economic status and are of poor health) opportunities to remain in the labour market are very low and they are in a very unfavourable position. Even though they may not wish to leave the labour market because additional earnings are necessary, they do not have the possibilities required to remain, in essence, they have no choice.

\section{CONCLUSION}

Initiatives for prolonging active working life often attract negative reactions. In Croatia there are many people who are against this prolongation, for they want to enjoy the pension to which they have become entitled as soon as possible, and there are only few who want to participate in the labour market any longer. Apart from that, there are many people who have spent their working lives in physically demanding occupations and those who, because of physical predispositions or care for their loved ones are not able to work any longer, while it can be assumed that for many, staying longer in the labour market is necessary for purely financial reasons. On the other hand, there are some who want and can work longer, a group whose health statuses were not negatively affected by the job they did, and perhaps have more chances for staying in the labour market, which is also not a rule. There can be no precise rule, for the older labour force is a particularly heterogeneous group and it is very unrewarding to draw unambiguous and universally applicable conclusions. In the Republic of Croatia those who have poorer education, health and finances have very few possibilities, that is, chances, of staying longer in the labour market.

The possibility of choosing to stay longer in the labour market is very essential, that is, the minimalization of the undesirable situation in which people who perhaps would like to prolong their working life are bound to abandon it and possibly to live in poverty.

In the Republic of Croatia, the chances of staying longer in the labour market are much greater for those who are highly educated and have a better material status, those that have the most opportunities, and there are very few of them, with the rider of course that in this group there are also some who do not wish to continue working.

Those who remain longer in the labour market in Croatia do so mainly out of financial needs, and the level of poverty of pensioners tells us that the number of those who need their incomes topping up is large, and we know that there will be more of them in the future. The role of all aforementioned factors that affect the labour market for older people, is to increase the possibilities such people have for work, as we have seen in the examples of Denmark and Portugal. 
In Croatia people leave the labour market quite early, but certain endeavours for prolonging the working life have been taken. Although a greater proportion of people opt to leave the labour market earlier (taking early retirement), raising the retirement age increased the labour force participation rate of the below-60s.

The legal framework disincentivizes longer stay in the labour market, linking it with 65 years, while institutions of phased or deferred retirement have not been widely applied. An active labour market policy has not been sufficiently adjusted to the needs of the labour market for older persons, the level of participation of the elderly in lifelong learning is very low, and the small share of highly educated older people partially explains to us the low labour force participation rate of the elderly.

Because of the heterogeneity of the group, the most important factor in adjusting the labour market to older people has been identified as working time flexibility. The adaptation of hours of work to individual needs is the main reason why in the world older workers are very often self-employed and work part-time. The labour market for older people in the Republic of Croatia diverges most from other countries in the very small share of people working part time, and the very low share of older self-employed persons, from which we can conclude that the labour market is not older-worker friendly.

All the countries from the comparison, to a larger or smaller extent, have a higher labour force participation rate than Croatia, although the educational structure, the conditions of the labour market for older people and the institutional conditions markedly differ, which proves that there is no universal model for prolongation of staying in the labour market.

A greater labour force participation rate contributes to greater economic growth and tax revenues, which is particularly important for countries with an adverse demographic picture and a large number of relatively young retirees. In the Republic of Croatia, the demographic picture gives cause for deep concern. The size of the labour force is diminishing, people are living longer, and leaving the labour market ever earlier. In the calculation we have ascertained that additional working capacity does exist, and the perception of older workers taking jobs away from younger can be refuted by a simple linear regression (appendix, graph A1). Hence, with respect to the undoubted need for prolongation of the working life and the fact that the economic situation is improving, there is an ideal opportunity for additional attempts to prolong working life. Primarily, the labour market should be adjusted to the needs of older workers according to those criteria that have been shown to work. If high quality possibilities of choice are provided, there will certainly be those who will soon accept and make use of them, and their example can then contribute to raising the awareness and changing the trends of a deeply rooted culture of early departure from the labour market.

\section{Disclosure statement}

No potential conflict of interest was reported by the authors. 


\section{GraPH A1}

Simple linear regression of trends in the rate of unemployed young in the 25 to 29 age group and of employed older workers from 55 to 64, from 2002 to 2016

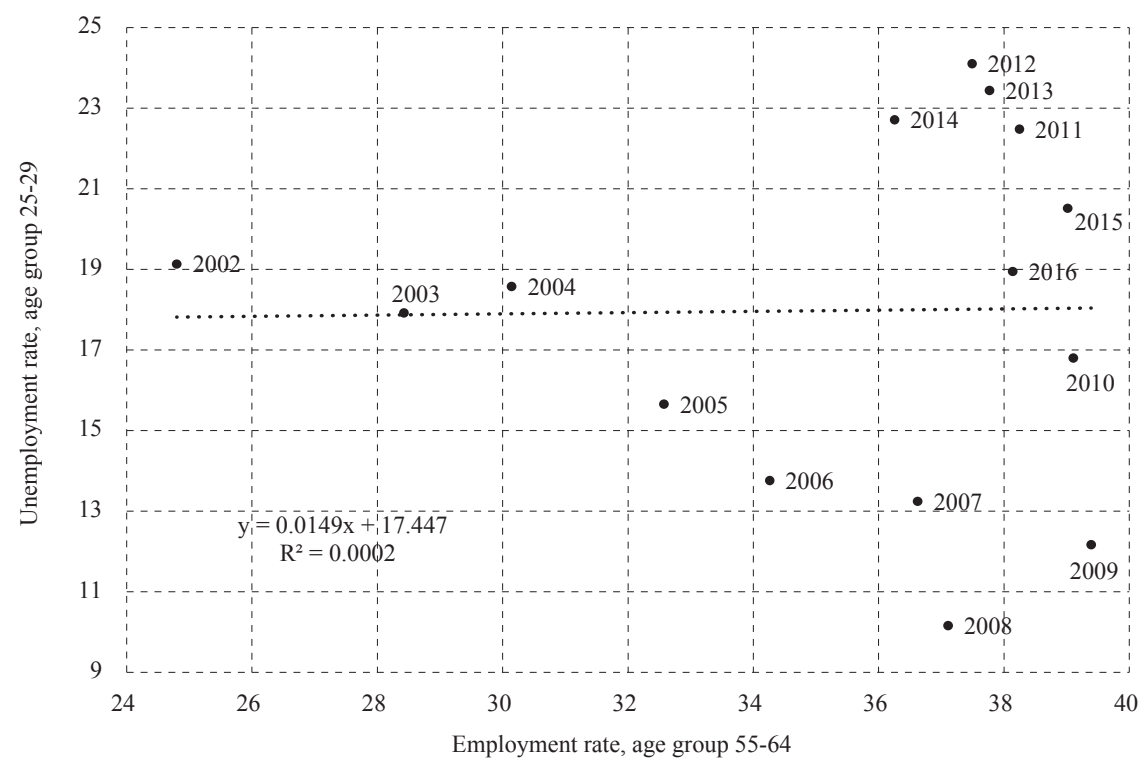

Note: there is no relationship between the two, even if for the same period we consider unemployment rate of other younger age groups, for example, from 20 to $24(R 2=0.00118)$ or from 25 to 34 ( $R 2=0.000533)$.

Source: authors' calculation based on the data from OECD.Stat, accessed April 27, 2018. 


\section{REFERENCES}

1. Act on Employment Mediation and Unemployment Rights, OG 16/17. Zagreb: Official Gazzete.

2. Akrap, A., 2006. Aktivni osiguranici i umirovljenici u Hrvatskoj - očekivani trendovi do 2031. godine. Revija za socijalnu politiku, 13(2) pp. 127-150 https://doi.org/10.3935/rsp.v13i2.429

3. Atkinson, J., 1984. Flexibility, Uncertainty and Manpower Management. IMS Report, No. 89.

4. Baloković, S., 2011. Prijevremeno umirovljenje u Republici Hrvatskoj. Revija za socijalnu politiku, 18(1), pp. 61-76. https://doi.org/10.3935/rsp.v1i1.976

5. Bergmann, M. [et al.], 2017. Survey Participation in the Survey of Health, Ageing and Retirement in Europe (SHARE), Wave 1-6. Based on Release 6.1.0 (March 2018). SHARE Working Paper Series 31-2017.

6. Blöndal, S. and Scarpetta, S., 1997. Early retirement in OECD countries: the role of social security systems. Economic Studies, No. 29. Paris: OECD.

7. Blöndal, S. and Scarpetta, S., 1999. The retirement decision in OECD countries. Economics department working papers, No. 202.

8. Börsch-Supan, A., 2018. Survey of Health, Ageing and Retirement in Europe (SHARE) Wave 6. Release version: 6.1.0. SHARE-ERIC. Data set. https://doi. org/10.6103/SHARE.w6.611

9. Börsch-Supan, A. [et al.], 2013. Data Resource Profile: The Survey of Health, Ageing and Retirement in Europe. International Journal of Epidemiology, 42(4), pp. 992-1001. https://doi.org/10.1093/ije/dyt088

10. Botrić, V. and Tomić, I., 2016. Self-employment of the young and the old: exploring effects of the crisis in Croatia. Working Papers, No. 1603.

11. Botrić, V., 2012. Regional differences in self-employment: evidence from Croatia. Ekonomska istraživanja, 25(1), pp. 243-266. https://doi.org/10.1080/ 1331677X.2012.11517564

12. Bredgaard, T., and Tros, F. 2006. Alternatives to early retirement? Flexibility and security for older workers in the Netherlands, Denmark, Germany and Belgium. Paper presented at the ILP Meeting Innovating Labour. Market Policies: Transitional Labour Markets and Flexicurity, 30 November - 1 December 2006, Amsterdam

13. Burtless, G., 2013. The impact of population aging and delayed retirement on workforce productivity. Working Paper, No.11. Boston: Center for Retirement Research (CRR).

14. Christelis, D. and Fonseca, R., 2015. Labor market policies and self-employment transitions of older workers. Cirano Scientific Series, No. 2015s-50.

15. Civil Servants Act, OG 61/17. Zagreb: Official Gazzete.

16. Coile, C., Milligan, K. S. and Wise, D. A., 2016. Social security and retirement programs around the world: the capacity to work at older ages - introduction and summary. NBER Working Paper, No. 21939.

17. Contributions Act, OG 115/16. Zagreb: Official Gazzete. 
18. Dalen, H. [et al.], 2006. Dealing with an ageing labour force: what do European employers expect and do? Netherlands interdisciplinary demographic Institute Report no. 73, Hague.

19. Decision No 940/2011/EU of the European Parliament and of the Council of 14 September 2011 on the European Year for Active Ageing and Solidarity between Generations (2012) Text with EEA relevance L 246, 23/9/2011, pp. 5-10.

20. Eichhorst, W. [et al.], 2013. How to Combine the Entry of Young People in the Labour Market with the Retention of Older Workers? IZA Discussion Paper, No. 7829.

21. Eurobarometer, 2012. Active ageing Report. Special Eurobarometer, No. 378.

22. Eurofound, 2012a. Employment trends and policies for older workers in the recession. Luxembourg: Publication Office of the European Union.

23. Eurofound, 2012b. Income from work after retirement in the EU. Luxembourg: Publications Office of the European Union.

24. Eurofound, 2016. Extending working lives through flexible retirement schemes: Partial retirement. Luxembourg: Publications Office of the European Union.

25. European Commission, 2013. Flexicurity in Europe, Final Report. Luxembourg: Office for Official Publications of the European Communities.

26. European Commission, 2015. Employment and Social Developments in Europe 2015. Brussels: European Commission.

27. Eurostat, 2018. Eurostat metadata. Eurostat.

28. Fortuny, M., Nesporova, A. and Popova, N., 2003. Employment promotion policies for older workers in the EU accession countries, the Russian Federation and Ukraine. Employment paper, No. 2003/50.

29. Gal, R. I., 2005. Keeping older workers in the labor market in Europe and Japan Survey of comparative literature 1st version. Tokyo: Japan Institute for Labour Policy and Training.

30. Ghosheh, N. S. Jr., Lee, S. and McCann, D., 2006. Conditions of work and employment for older workers in industrialized countries: Understanding the issues. Conditions of Work and Employment Series, No. 15.

31. Gruber, J. and Wise, D. A. (eds.), 2010. Social Security Programs and Retirement around the World: The Relationship to Youth Employment. Chicago and London: The University of Chicago Press. https://doi.org/10.7208/chicago/ 9780226309507.001.0001

32. Gruber, J., Milligan, K. and Wise, D. A., 2009. Social Security Programs and Retirement Around the World: The Relationship to Youth Employment, Introduction and Summary. NBER Working Paper, No. 14647.

33. Heywood, J. S. and Siebert, W. S., 2009. Understanding the Labour Market for Older Workers: A Survey. IZA Discussion Paper, No. 4033.

34. Hochguertel, S., 2010. Self-Employment Around Retirement Age. Tinbergen Institute Discussion Paper, No. 10-067/3. http://dx.doi.org/10.2139/ssrn.1692708 
35. HZMO, 2002. 80 godina mirovinskog osiguranja u Hrvatskoj. Zagreb: HZMO.

36. HZMO, 2018. Statističke informacije HZMO-a. Zagreb: HZMO.

37. HZZ, 2016. Vanjska evaluacija mjera aktivne politike tržišta rada 2010. - 2013. Zagreb: HZZ.

38. ILO, 2013. The ILO Older Workers Recommendation, 1980 (No. 162). Geneva: ILO.

39. ILO, 2013a. Report IV Employment and social protection in the new demographic context International Labour Conference, 102nd Session, 5 - 20 June 2013. Geneva: ILO.

40. ISSA, 2017a. Social Security Programs Throughout the World: Europe, 2016. SSA Publication, No. 13-11801. Washington DC: Social Security Administration Office of Retirement and Disability Policy (SSA).

41. ISSA, 2017b. Social Security Programs Throughout the World: Asia and the Pacific, 2016. SSA Publication, No. 13-11802. Washington DC: Social Security Administration Office of Retirement and Disability Policy (SSA).

42. Johnson, R. W. and Kawachi, J., 2007. Job changes at older ages effects on wages, benefits, and other job attributes. The Program on Retirement Policy Discussion Paper, No. 07-03.

43. Kalwij, A., Kapteyn, A. and de Vos, K., 2009. Early Retirement and Employment of the Young. RAND, Labour and Population Working Paper Series, No. WR-679.

44. Kantarci, T. and Soest, A., 2008. Gradual retirement: preferences and limitations. De Economist, 156(2), pp. 113-144. https://doi.org/10.1007/s10645008-9086-1

45. Komp, K., Tilburg, T. and Broese van Groenou, M., 2010. Paid work between age 60 and 70 years in Europe: a matter of socio-economic status? International Journal of Ageing and Later Life, 5(1), pp. 45-75. https://doi.org/ 10.3384/ijal.1652-8670.105145

46. Konle-Seidl, R., 2017. Retention and Re-integration of older workers into the labour market: What works? IAB Discussion Paper Articles on labour market issues, No. 17.

47. Labour Act, OG 127/17. Zagreb: Official Gazzete.

48. Malter, F. and Börsch-Supan, A. (eds.), 2017. SHARE Wave 6: Panel innovations and collecting Dried Blood Spots. Munich: MEA.

49. Mandatory Health Insurance Act, OG 80/13 and 137/13. Zagreb: Official Gazzete.

50. Mayhew, K. and Rijkers B., 2004. How to improve the human capital of older workers or the sad tale of the magic bullet. A paper prepared for the joint ECOECD Seminar on Human. Capital and Labour Market Performance, December 8, 2004.

51. Milligan, K. and Wise, D. A., 2012a. Introduction and Summary In: D. Wise (ed.) Social Security and Retirement around the World: Historical Trends in Mortality and Health, Employment, and Disability Insurance Participation 
and Reforms. Chicago: University of Chicago Press and NBER, pp. 1-39. https://doi.org/10.7208/chicago/9780226921952.003.0001

52. Milligan, K. S. and Wise, D. A., 2012b. Health and work at older ages: using mortality to assess the capacity to work across countries. NBER Working Paper, No. 18229.

53. Munnell, A H. and Wu, Y., 2013. Do Older Workers Squeeze Out Younger Workers? Discussion Paper, No. 13-011.

54. Nestić, D. and Rašić Bakarić, I., 2008. From work to retirement: Pension system incentives to continued labour market participation in Croatia In: M. Vehovac (ed.). New perspectives on a longer working life in Croatia and Slovenia. Zagreb: Ekonomski institut and Friedrich Ebert Stiftung, pp. 81-100.

55. OECD, 2017. Pensions at a Glance 2017: OECD and G20 Indicator. Paris: OECD.

56. Ograjenšek, I. [et al.], 2008. Employer attitudes towards older workers: A comparative study of Croatia and Slovenia In: M. Vehovac (ed.). New perspectives on a longer working life in Croatia and Slovenia. Zagreb: Ekonomski institut and Friedrich Ebert Stiftung, pp. 119-140.

57. Pension Insurance Act, OG 157/13, 151/14, 33/15, 93/15, 120/16, 18/18. Zagreb: Official Gazzete.

58. Phillipson, C. and Smith, A., 2005. Extending working life: A review of the research literature. Research Report, No. 299.

59. Principi, A. [et al.], 2015. Characteristics of working pensioners in Italy: between early retirement tradition and reforms to extend working life In: S. Scherger (ed.) Paid work beyond pension age: comparative perspectives. London: Palgrave Macmillan, pp. 81-106. https://doi.org/10.1057/ 9781137435149_4

60. Puljiz, V., 2007. Hrvatski mirovinski sustav: korijeni, evolucija i perspektive. Revija za socijalnu politiku, 14(2), pp. 163-192. https://doi.org/10.3935/rsp. v14i2.698

61. Qi, H., 2016. Live Longer, Work Longer? Evidence from Sweden's Ageing Population. Doctoral thesis. Lund: Lund University.

62. Reischl, U., 2007. Health and safety issues of older workers. Sigurnost, 49(2), pp. 125-130.

63. Rutkowski, J., 2007. From the Shortage of Jobs to the Shortage of Skilled Workers: Labor Markets in the EU New Member States. IZA Discussion Papers, No. 3202.

64. Samorodov, A., 1999. Ageing and labour markets for older workers. Employment and training papers, No. 33.

65. Scherger S., 2015. Introduction: Paid Work Beyond Pension Age - Causes, Contexts, Consequences In: S. Scherger (ed.) Paid Work Beyond Pension Age: comparative perspectives. London: Palgrave Macmillan, pp. 1-27. https://doi. org/10.1057/9781137435149_1

66. Scherger, S. [et al.], 2012. Between Privilege and Burden. Work Past Retirement Age in Germany and the UK. ZeS-Working Paper, No. 04. 
67. Schloss, D. F., 1891. Why Working-Men Dislike Piece-Work. Economic Review, 1(3), pp. 311-326.

68. Sewdas, R. [et al.], 2017. Why older workers work beyond the retirement age: a qualitative study. BMC Public Health, 17(672). https://doi.org/10.1186/ s12889-017-4675-z

69. Social Protection Committee, 2007. Promoting longer working lives through pension Reforms, First part Flexibility in retirement age provision Report. Brussels.

70. Stubbs, P. and Zrinščak, S., 2017. Policy vacuum in the face of a new wave of emigration from Croatia. European social policy network Flash Report, No. 2017/50.

71. United Nations, 2015. World Population Ageing 2015. New York: Department of Economic and Social Affairs, Population Division.

72. Wahrendorf, M. [et al.], 2017. Who in Europe works beyond the state pension age and under which conditions? Results from SHARE. Journal of Population Ageing, 10(3), pp. 269-285. https://doi.org/10.1007/s12062-016-9160-4 